\title{
BETANG, A TRADITIONAL HOUSE OF THE DAYAK NGAJU IN BORNEO ITS SPACE RELATED TO STRUCTURE
}

\author{
MANDARIN GUNTUR ${ }^{1 *}$, KEMAS RIDWAN KURNIAWAN ${ }^{2}$, YUNITHA $^{3}$ \\ $1 *$ \\ Department of Architecture \\ University of Indonesia. \\ Campus Depok. Jawa Barat. Indonesia \\ email: mandarin.guntur@gmail.com, URL: https://architecture.ui.ac.id \\ ${ }^{2}$ Department of Architecture \\ University of Indonesia. \\ Campus Depok. Jawa Barat. Indonesia \\ email:kemas.ridwan@gmail.com, URL: https://architecture.ui.ac.id \\ ${ }^{3}$ Department of Architecture \\ University of Palangka Raya, Indonesia \\ Campus UPR, 73111 Palangka Raya, Indonesia \\ e-mail: ynitha@yahoo.com,web page: https://www.upr.ac.id
}

Keywords: Borneo, Dayak-Ngaju, Betang, Space, and Structure

\begin{abstract}
The ancient structures of the tribes in the globe yearn to conserve. It marks their races as natives of those places. Nowadays, some of those buildings have lost through natures and cultures. This study aims to get the pieces of knowledge of the Dayak Ngaju tribe. In a structure that calls as Betang. It formed of bases, cavities, floors, walls, and roofs. As known, some of these buildings have ruined, only a few of them still stand. The methods of research led to qualitative and descriptive. It is the way to get the results. At first, Betang reviewed through the critical comparisons of the elements and space backgrounds. Then, took some points in the hypotheses, once it structures analyzed. With the processed amongst functions, ties, measures, forms, and its parts fit the old. Hence, the appraisal gave the rest of the structures formed in percentages. These sums use as conservation values. The reviews were on the profer Dayak villages sort of Tumbang Gagu, Anoi, Malahoi, and Korik. It gave samples through sketches, pictures, and some interviews. It helped to finish the research. Study proves that Betang has left $42 \%$ off its old structured elements. It is a form that shaped the spaces.
\end{abstract}

\section{INTRODUCTION}

Betang is a big traditional house of the Dayak Ngaju tribe in Borneo. In many years, Betang promoted a wooden architectural characteristic. Due to cultural distillation, technology and builders whom fully unknown on how to build betang alike its original structure, then this house became slowly disappeared $[6,16,17]$. Betang in Dayak Ngaju comes in two phases of design. First, as a structure designed by approaching the belief and experience of their leader. The second based on material availability, technology, and transportation [17]. Commonly, Betang construction involved many people to build. It was 
also as a symbol and as a pride to their ancestors $[6,17]$. People of Dayak believe that the ancestor has done to the deity is a trajectory vision including how to build the Betang [4].

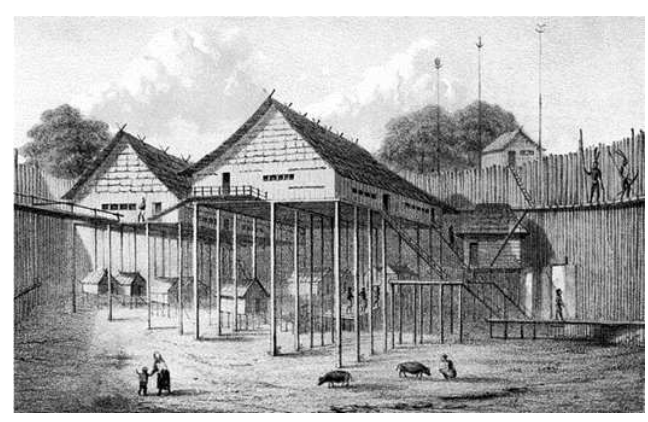

Figure 1. Betang Bakota (fortified) in Central Borneo [23]

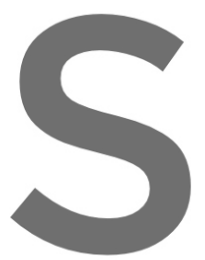

Figure 3. Betang Tumbang Malahdi in Central Borneo (source: 2006)

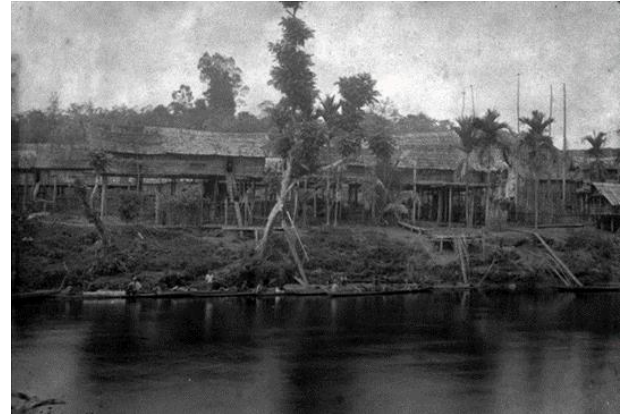

Figure 2. Betangs in Tumbang Anoi in 1894 (source: Tropenmuseum)

Register for free at https//www.scipedia.com to download the version without the watermark Dayak tribe's belief that the ground is the world of hades when death comes. People will

go to hades as the temporary place before getting into solemn in the death rituals that famous

as Tiwah [12]. Within this, they belief that man comes from the darkness. So that, the ritual to begin in the middle of the night, when the clock touches 00.00 or $12.00 \mathrm{am}$. It means that the dead man must already stay with their ancestry. At the same time, the priest will state that someone who had carried to heaven, ready arrived at its destination. Thus, the priest lay down the bones of the dead man inside the coffin and put it on the highest place. In this case, it was on the stair of the Betang. Hereafter, the bones transfers to the Sandung (heaven alike a Betang but mini) $[12,14]$. Some people who belief in the Kaharingan religion still making this $[17,6]$. Hence, to accommodate this structure still sustain, the conservation of Betang is necessary to avoid them from loss through natures and cultures.

\section{STRUCTURE AND CONSTRUCTION IN BETANG}

Before Dayak conciliation in 1894, forests in Borneo provided many resources such as ironwood and other materials for construction. Using pickaxe and knife, people of Dayak construct Betang (see figure 10). According to its construction ages, Betang in Tumbang Gagu that constructed in 1873, younger than in Tumbang Malahoi (in 1869) and Tumbang 
Anoi (in 1868) [3]. Betang comes in rectangular with a gable roof. Its length about 63 depe and wide about 10 depe (one depe equal to 1.70 meters). It was high about three (3) meters or more above the ground.

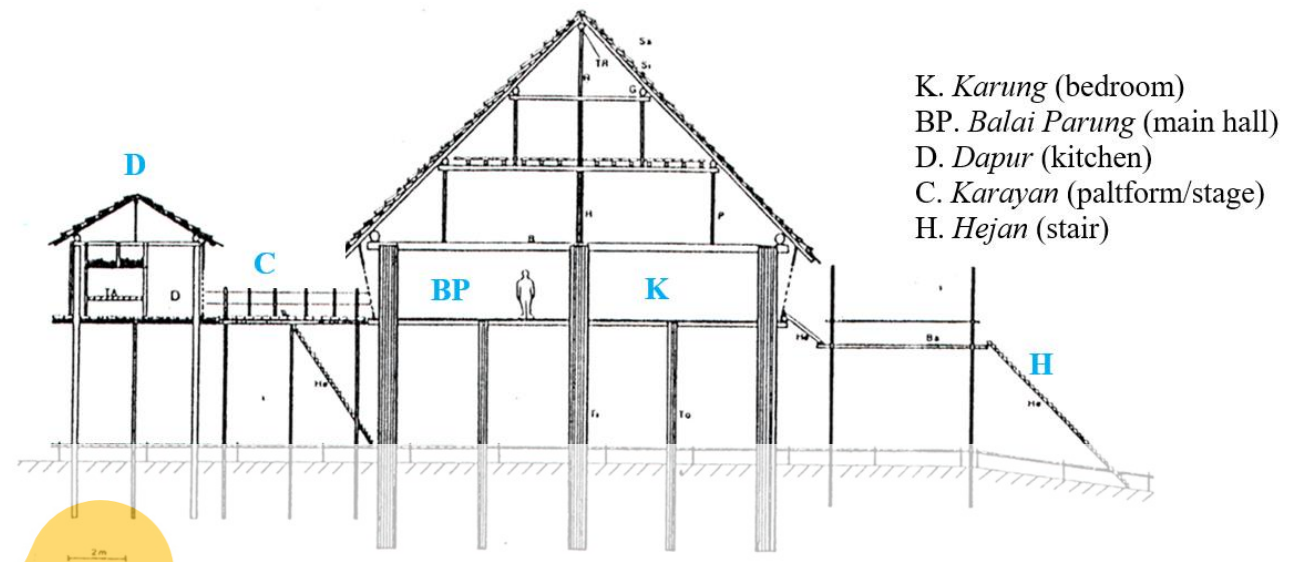

Figure 5. Section of Betang Tumbang Gagu structured in 1873 [3]

Betang consists of components as follows: Batang-Huma is the main room that functions as a living room (hall) and bedroom (karung). Dapur is a kitchen room and Karayan is a space

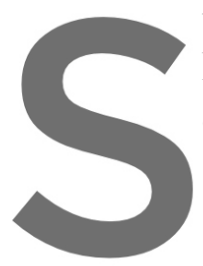
that connects the living house that functions about $1-1.5$ meters abor
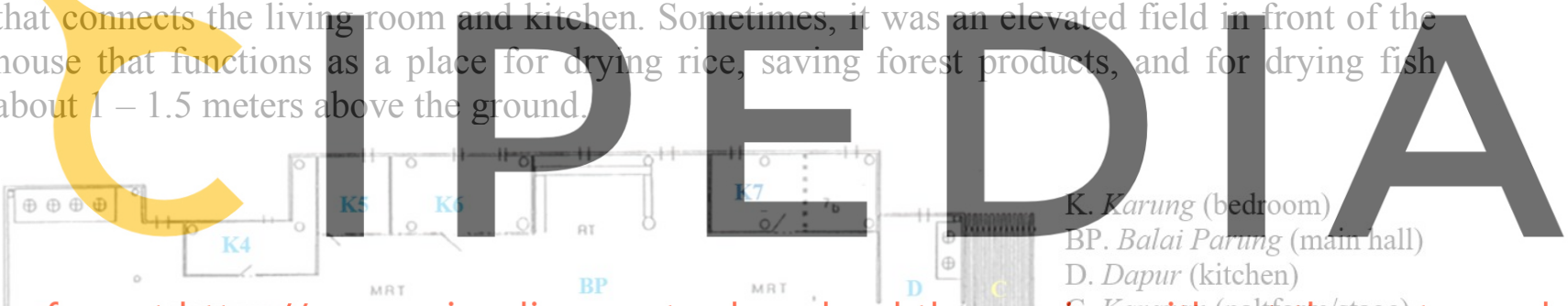

Register for free at https//www.scipedia.com to download the versfo fawwithoultothetatermark

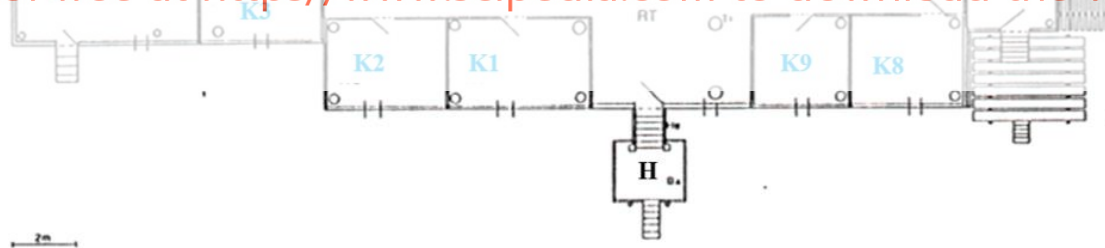

Figure 6. Plan of Betang in Tumbang Malahoi (source: Sakoh 1920) [3]

The pillars of Betang as the first element of Betang designed following the tarah system to count its diameters. This system was following the measurement of pickaxe incision on the pillar. One (1) tarah is equal to $4-5$ centimeters. Jihi (as the main pillars) should come from the ironwood that shouldering the entire construction load from the rooftop until the foundation then delivers it to the ground. Tungket (pillars/stick) is a supporting pillar to shoulder the floor. Commonly, the height of supporting pillars is around 2.29 meters. The main pillars composed tiang bakas (the first pillar/32 tarah) until tiang busu (the youngest pillar/ 22 tarah) with the height around 5.58 meters above the ground. The second element is on the floor. It consists of ironwood board that incisions use pickaxe (tarah) along the 4-5 meters. The wide of the board is around 30-40 centimeters. 


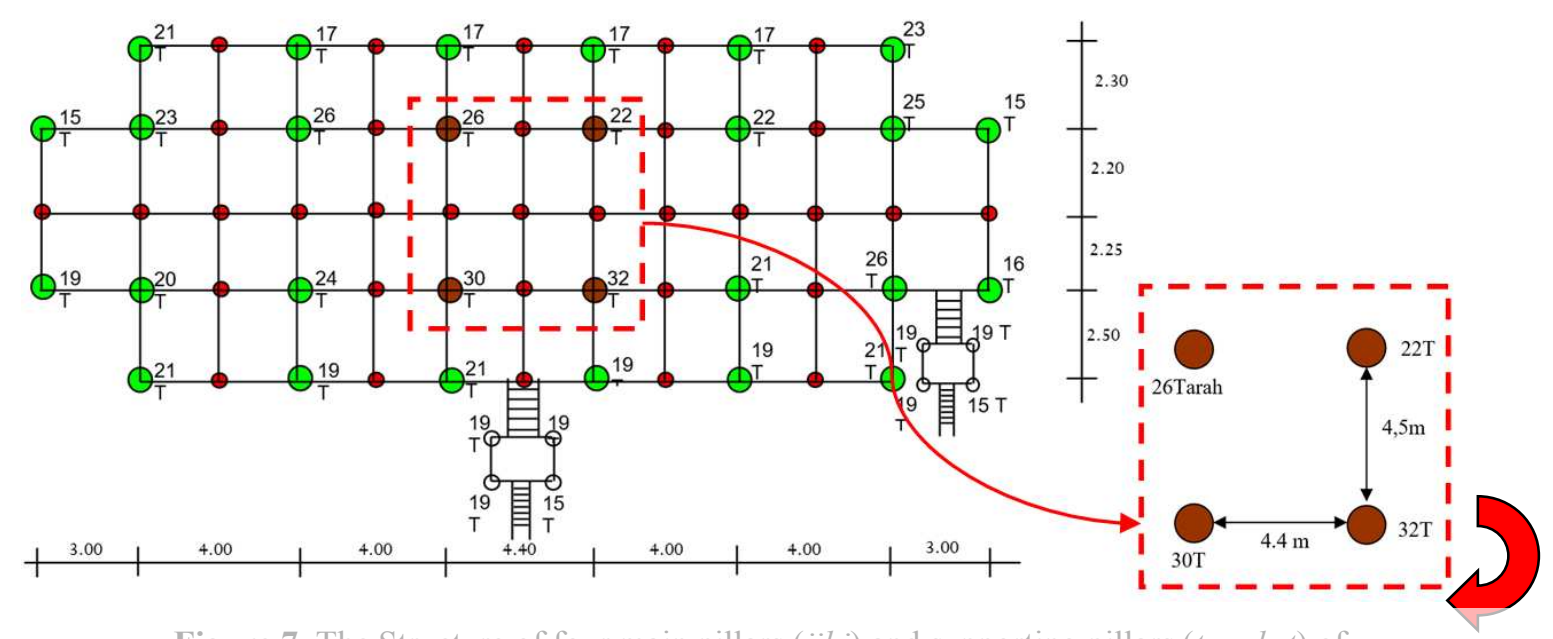

Figure 7. The Structure of four main pillars (jihi) and supporting pillars (tungket) of Betang Tumbang Malahoi (source: investigation 2006)

The pillars of Betang as the first element of Betang that laid upon handaran (the floor balk that used to be a log laid upon the supporting pillars or connected to the main pillars) and the joint on this construction use a wooden pin or rattan tied. The third element is the wall. It comes from the skin of trees (wooden pendu) that tied, neatly arranged, and already cleaned.

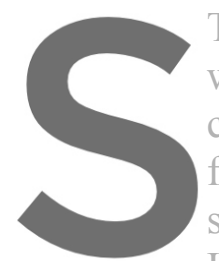
The last element of donstruction is the rooftop that composdd using sirap (thin and smooth wooden board), its wide 40 centimetors and 80-100 centimeters length. The order of sirap composes ashlar patterns. How to people of Dayak constructs the main pillar of Betang? The first step, chosen the location of the pillar or they called it as the oldest one (tiang bakas). The second, they dug the ground around $1-2$ meters deep. Then inserted the pillar into the hole. How to erect those pillars? The pillar that around $300 \mathrm{~kg}$ should lift by many person-using traditional caterpillars and on the tip of the pillar tied by special rattan, and then people

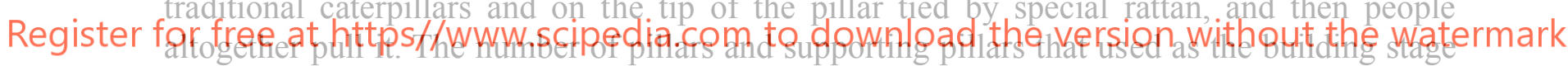
are arranged in a regular pattern, with the hierarchy from the old to the youngest (see fig. 6 , 7 and 11).

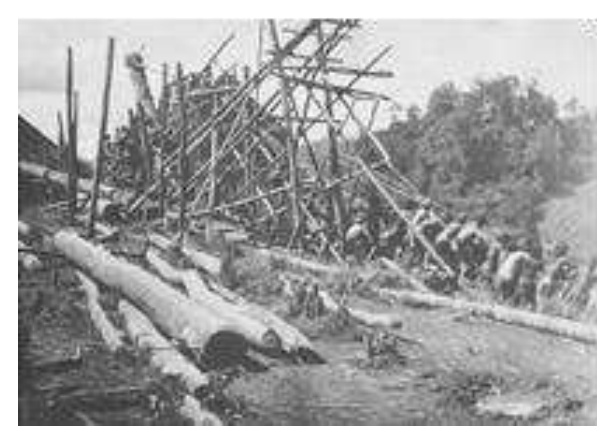

Figure 8. People of Dayak erected a pillar (jihi) of Betang (Source: Tropen museum, the Netherlands.)

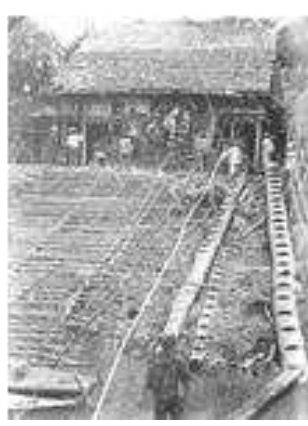

Figure 9. People of Dayak moved the material of Betang from river (Source: Tropen museum.

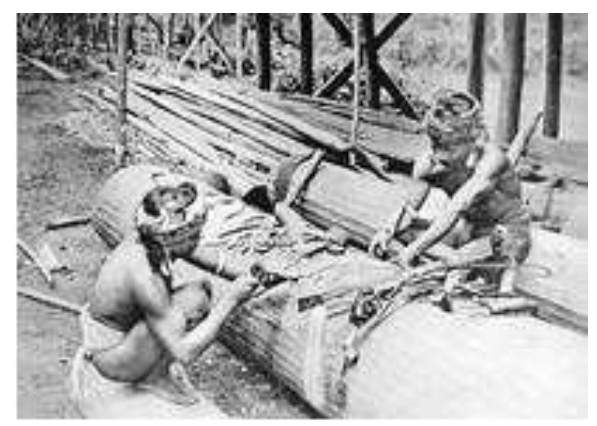

Figure 10. Dayak people carved the oldest pillar (jihi bakas), using knife (langgei) and pickaxe (beliung) (Source: Tropen museum, the Netherlands 
Betang for people of Dayak Ngaju are togetherness, unity and strengths. It means all of their descendances should come in conception of one Betang. Therefore, Betang design come in rigid, straight, and equilibrium.

\section{SPACE IN BETANG}

In Betang, besides the interior, exterior and transition space, there is heavenly space that drawn on the sandung (a place of dry bones) [14]. This kind of space calls as subjective space, a space that signified as vertical symbols, of the upper and lower realms $[10,15]$. Meanwhile, the daily spaces are a space from dawn to twilight, changing seasons, past and future history, depicted in the jihi bakas, as a symbol of orientation that determines the right hand kan-ngawa (downstream), kan-ngaju (upstream), kan-ngambu (top), and kan-ngiwa (ground) (see fig. 11). This kind of space called as an objective space [15].

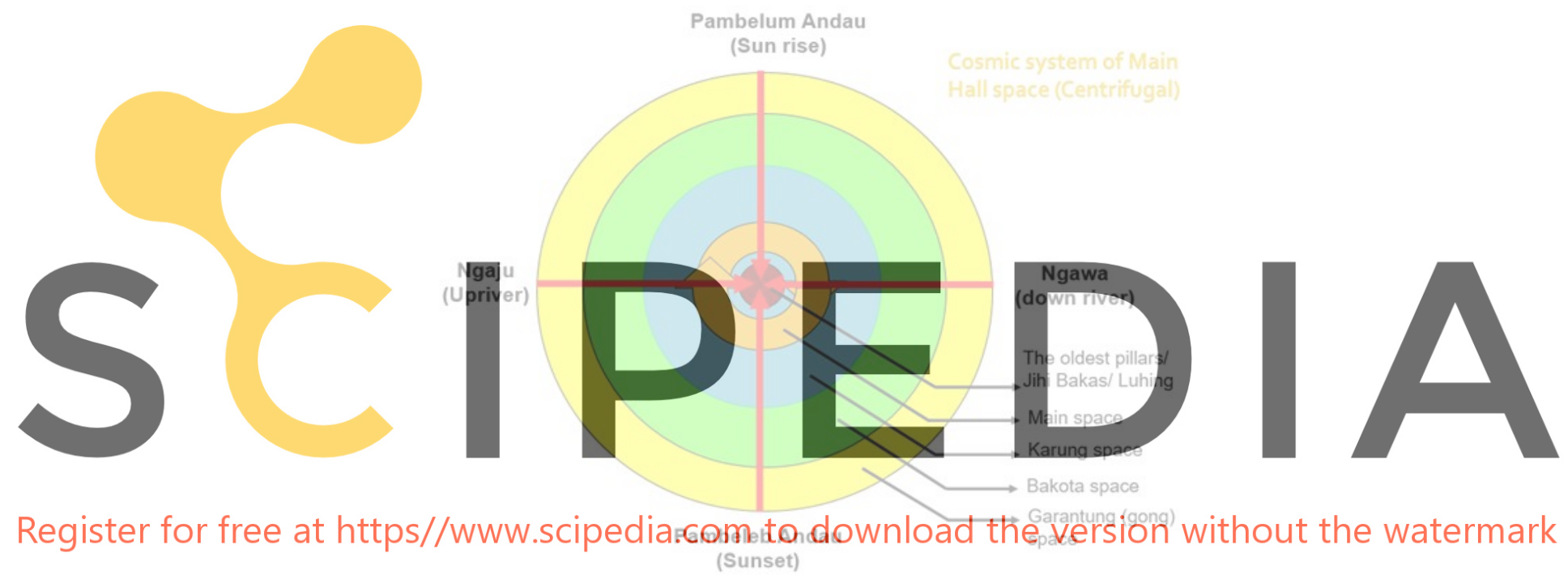

Figure 11. Cosmic system of Dayak Ngaju Modified from Scharer [12]

Betang also centre of Dayak Ngaju orientation, which means a spot where all people come back, as the first and the end [6,12]. Therefore, Betang become a system of cosmos that determined a spot meeting between the East and the West (see fig. 11).

\section{STRUCTURE ANALYSES FOR CONSERVATION}

Conserving Betang as a historical building is always interconnection between preservation and modernization. The historic monument conservation should manage the processes of renovation and revitalization like memorialized the past and as eloquently as represented the past [7]. According to Matero [9], the prominent objective of traditional building conservation is protecting cultural heritage from loss and damage. Conservators should accomplish this via both deterrent and curative types of intervention. Meanwhile, Reyden, D [2] cites that material care and materials science are both essential elements in any entire conservation program, incorporated within key functions of preservation administration, replication, environmental control, collections upkeep, preservation treatment, investigation and school. 
Therefore, through these meaning, Betang reveals its structure as a building element separated its construction technology into based, floor, wall, door, stair and roof, [11]

\subsection{Based (foundation)}

Generally, foundation of Betangs using many pillars and nearly having the same techniques for each Betang suited to their location where those materials to be found.

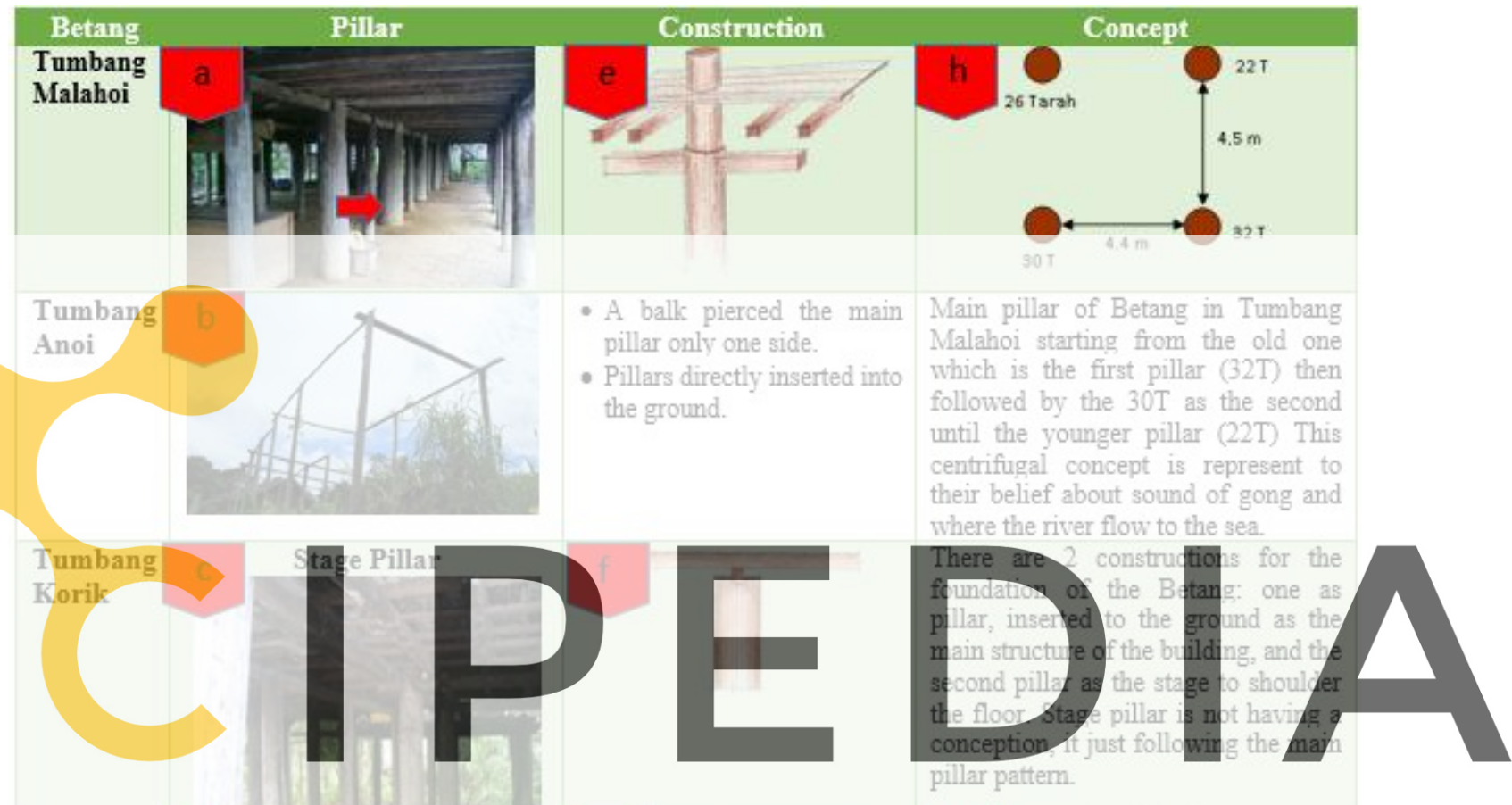

Register for freeag https//www.scipedia.com to download the version without the watermark
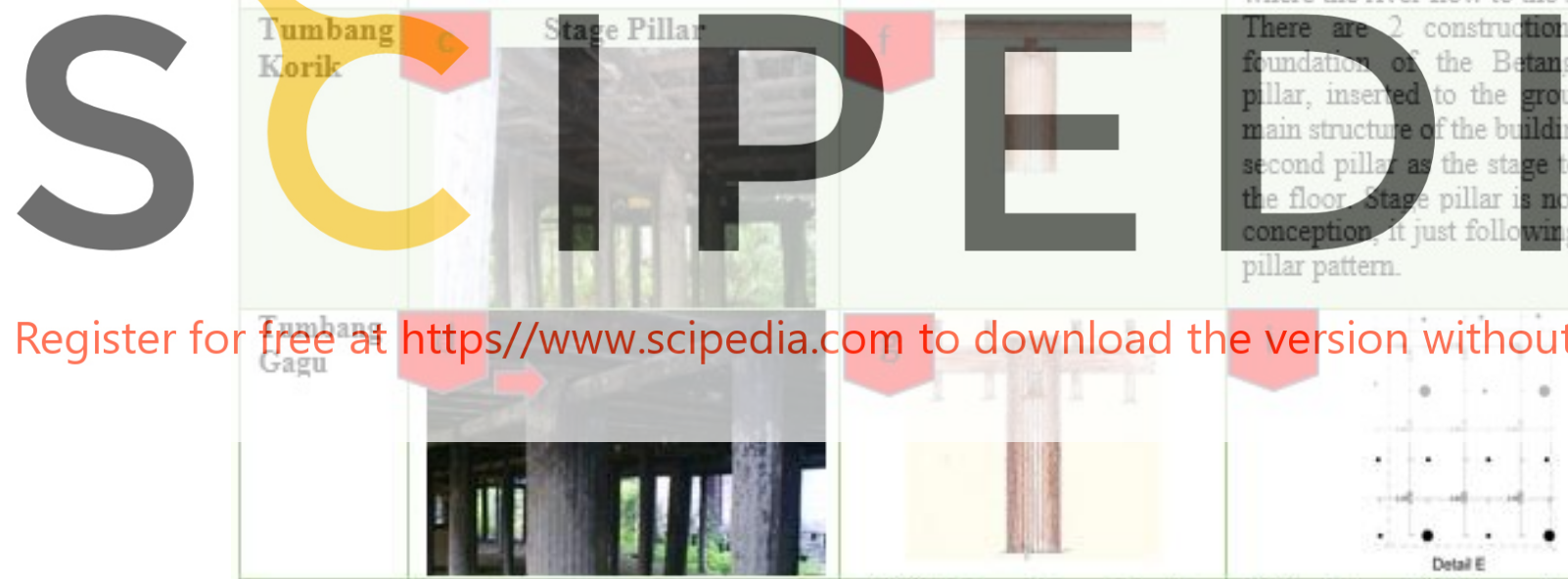
A balk pierced the main pillar
through two sides

Main pillar of Betang in Tumbang Gagu starting inserted to the ground from the oldest one then the other following the manner of centrifugal conception.

a. Pillar of Betang Tumbang Malahoi (source: observation in 2006). T (Tarah) is a measurement of Dayak for one pickaxe carving on the pillar about more or less $4-5$ centimetres wide.

b. Pillar of Betang Tumbang Anoi (source : observation in 2006)

c. Stage Pillar of Betang Tumbang Korik (source : observation in 2010)

d. Main Pillar of Betang Tumbang Gagu (source: observation in 2016)

e. Sketch of main pillar construction at one side pierced balk.

f. Sketch of the stage pillar of Betang construction.

g. Sketch of main pillar construction at two sides pierced balk.

$\mathrm{h}$. Sketch of the concept of main pillar manner in construction according to its age, from the oldest to the youngest one.

i. Sketch of the concept of main pillar and stage pillar in Betang Tumbang Gagu.

Figure 12. Pillars of Betang in Conception and Construction 
The only pillar of Betang in Tumbang Anoi has rotten dan ruin because it lay down in open area and did not preserved properly. Meanwhile, other pillars of Betang in Tumbang Korik, Tumbang Malahoi and Tumbang Gagu are still standing because it still occupied in and secured by other construction.

\subsection{Wall, Cavity and Stair}

Wall of Betang commonly using tree skin. When Schwaner came to Tumbang Malahoi in Dec 27, 1848, temperature in his thermometer was $25.6^{\circ} \mathrm{C}$. According to level of comfort, those temperatures are still between $16^{\circ} \mathrm{C}-26^{\circ} \mathrm{C}$. With this concept, there is split cavity between the skins of trees that given the breeze easily come in and out [5]. So that, Betang is not a solid Building. In there, people felt the breeze both at night and day. The wall of Betang, commonly about $2.50-2.75$ meters height.

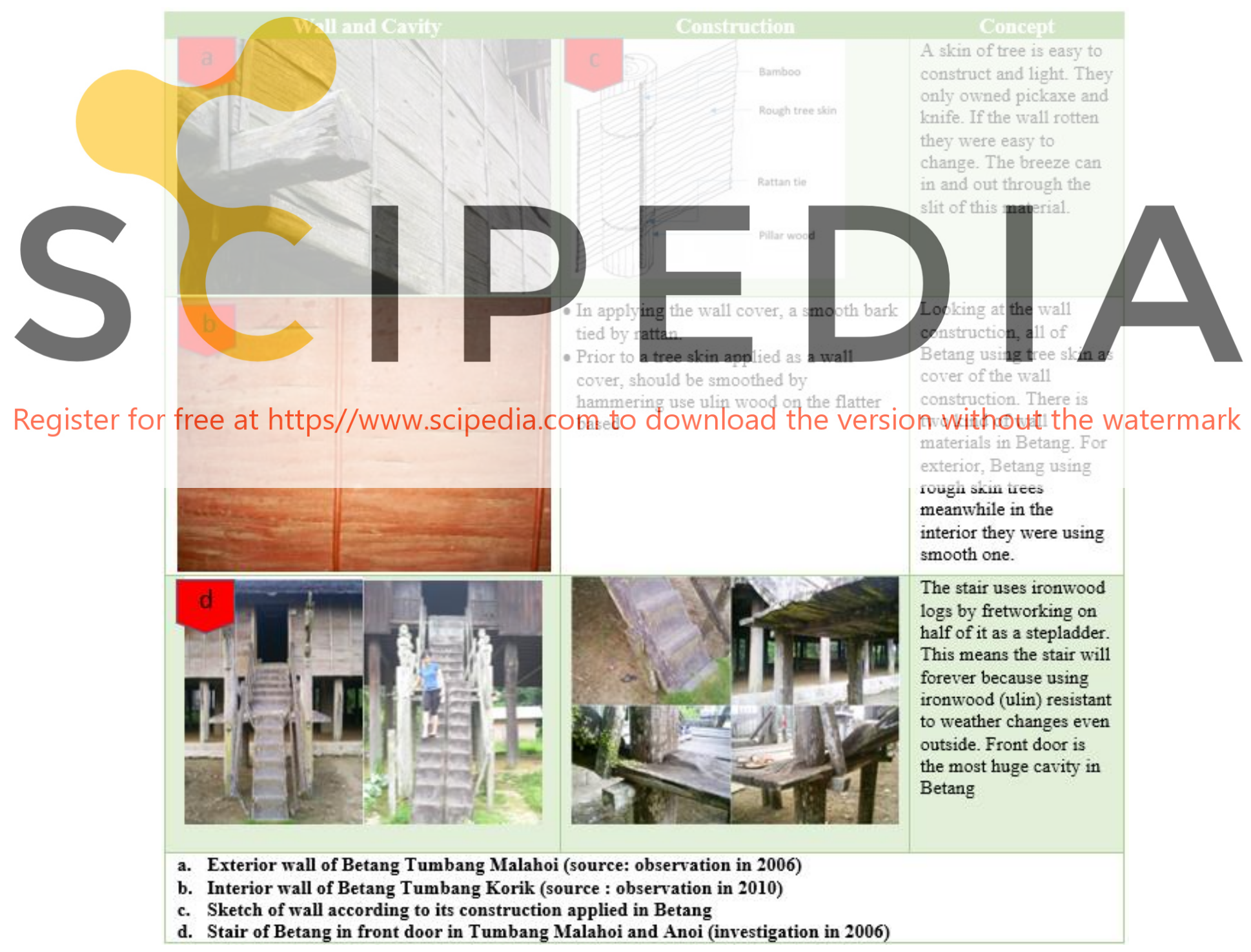

Figure 13. Walls, Cavity and Stair of Betang in Conception and Construction 
Of all Betang that still exist until now, is only Betang in Tumbang Malahoi the exterior wall still using rough tree skin.

\subsection{Floor}

The early Betang that ever recorded was Betang Tumbang Anoi in 1868. The construction of Betang floor originally using a small timber or bamboo [12]. The floor of Betang placed on the stage poles pillars around 3-4 meters above the ground. At that time, all construction using rattan tied and origin wood materials.

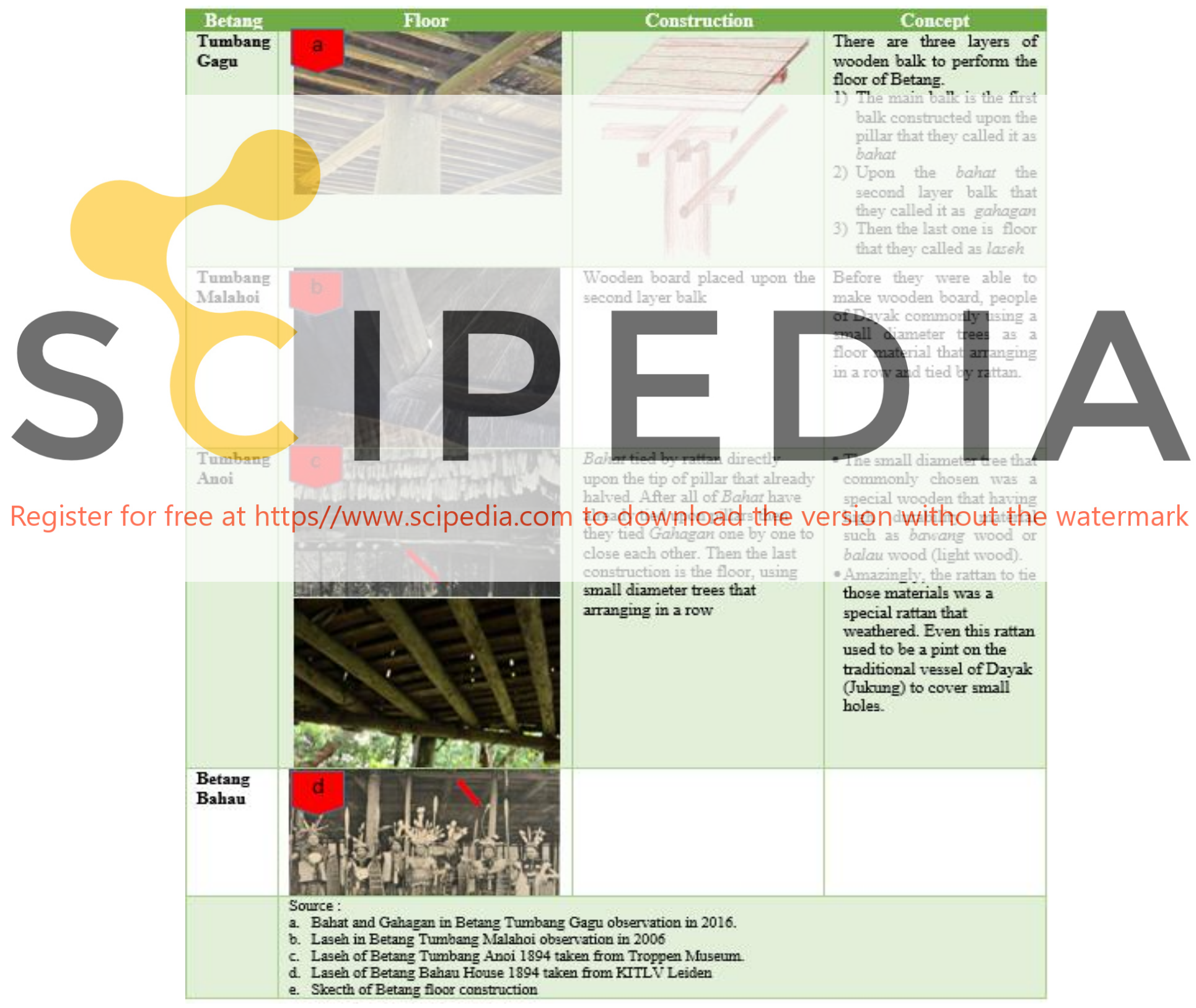

Figure 14. Floors of Betang in Conception and Construction 
Looking at Betang house of Bahau in East Borneo at the same age[d], they were using rattan tied as one of their main floor constructions. This happen equal to the Betang in Tumbang Anoi in 1894 when the first Dayak conciliation occurred [c]. Nevertheless, Betang in Tumbang Gagu [observation in 2016] and Tumbang Malahoi [observation in 2006] the floors of Betang have been transformed to the solid wood material (ironwood).

\subsection{Roof.}

Betang roof construction comes with difference types because of many reasons. It was depending on the condition of its Betangs. Actually, Betang in Tumbang Anoi as one of the oldest Betangs in Dayak Ngaju, so that its construction still using original material.

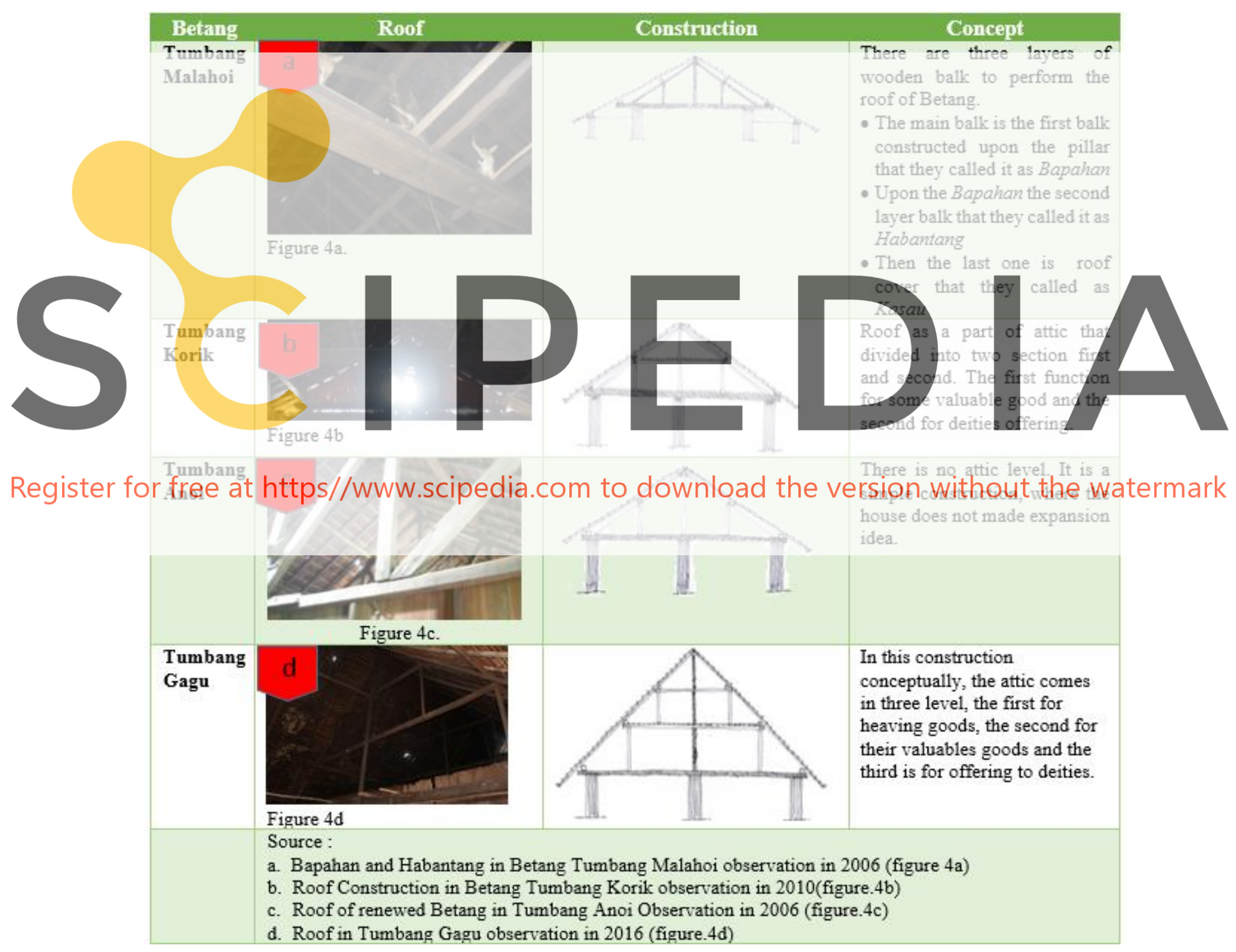

Figure 15. Roofs of Betang in Conception and Construction 


\subsection{Betang Assesment for Conservation}

In order to assess the change of Betang composition the value using percentage of the transformation structure of construction from its origin until today. These values can be changed according to its actual transformation or modification today.

Table 1. Conservation Assessment to Traditional House of Dayak Ngaju.

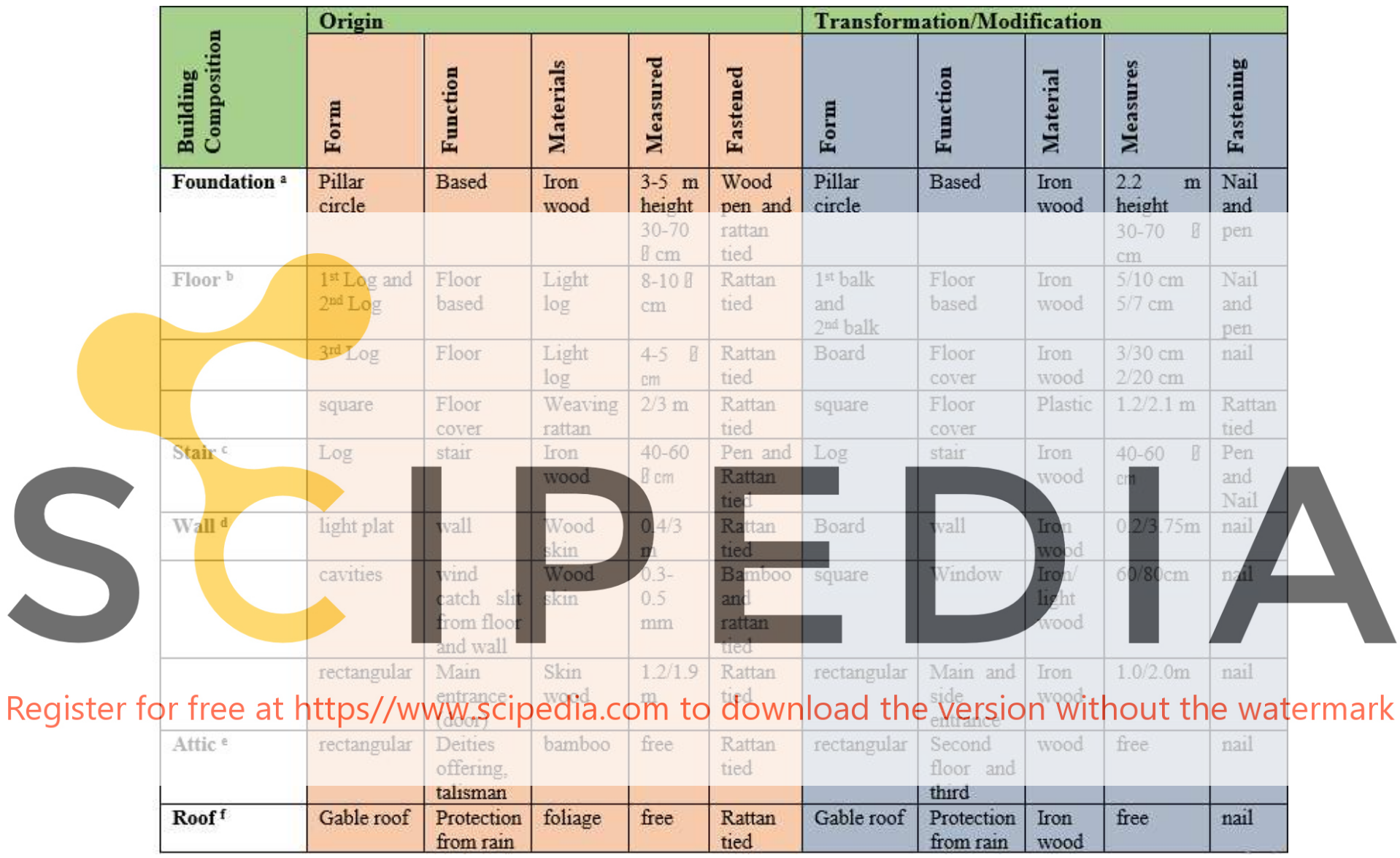

Source: Analyses, 2019

a. Betang in Tumbang Malahoi, its floor used to be 3-5 meters in height when Schwaner came to Tumbang Malahoi in 1846-1847, then the investigation in 2006 found the height of those pillars decreased to 2.2 meters from the ground. In the Traditional Architecture seminar at the University of Palangka Raya in 2002, head officer of Education and Culture Central Borneo province Drs. Kiwok Rampai said that he was made restoration the Betang at Tumbang Malahoi after fire disaster in 1988.

b. Of all betang floor in Borneo before 1894 using light log tied by rattan but now it has modified being an ironwood board fastened by nail and pin [12].

c. One of the oldest stairs of Betangs that still exist until now is in Betang at Tumbang Anoi (the first International Dayak conciliation in 1894 organized by West Kalimantan East Indische afdelling and Damang Batoe (Dayak leader of Ot-Danum tribe).

d. None of those Betangs that still using wood skin as its wall material, it is only Betang in Tumbang Malahoi that still using it as it happens today. 
e. Two of Betangs in Dayak Ngaju that still using attic as its function is in Betang Tumbang Gagu and Betang Tumbang Korik.

f. Betang roof comes in various styles concurrent to its function but most of all come in gable roof and $100 \%$ have changes its material using ironwood.

Table 2. Betang Dayak Ngaju appraisal on Building structure elements

\begin{tabular}{|l|c|c|c|c|c|c|}
\hline Compositions & Form & Function & Material & Measure & Fastening & Total \\
\hline Foundation & $100 \%$ & $100 \%$ & $100 \%$ & $80 \%$ & $50 \%$ & $86 \%$ \\
\hline Floor & $10 \%$ & $100 \%$ & $10 \%$ & $5 \%$ & $10 \%$ & $27 \%$ \\
\hline Stair & $100 \%$ & $100 \%$ & $100 \%$ & $100 \%$ & $90 \%$ & $98 \%$ \\
\hline Wall & $40 \%$ & $100 \%$ & $5 \%$ & $10 \%$ & $5 \%$ & $32 \%$ \\
\hline Attic & $100 \%$ & $10 \%$ & $5 \%$ & $100 \%$ & $5 \%$ & $44 \%$ \\
\hline Roof & $85 \%$ & $100 \%$ & $5 \%$ & $100 \%$ & $5 \%$ & $59 \%$ \\
\hline
\end{tabular}

Following the result within the table 2 depicted the foundation of Betangs that used to be using ironwood have changed its measuring and its fastening to $86 \%$. Betang floor shows the value $27 \%$, means the floor modified far away from its origin. Originally, Betang floor using logs that tied by rattan (see fig. 5c, 5d on Betang Bahau and Betang Tumbang Anoi in 1894) then transformed using wooden beam (fig.5a, 5b and 5c in 2016). Meanwhile, stair is the element of Betang that still exist and does not much transformed just $98 \%$ from its origin. The other compositions are wall, at first design using wooden skin but have transformed to $32 \%$, only left its function that still using as the wall. The attic of Betang left its composition to $44 \%$ and now it merely used for talisman place and offerings for deities. The last element is the roof. Maybe function and measures still at the same of its origin but its form, material and its fastening have so much changed to $59 \%$. Which mean that this transformation values have modified its roof construction. Overall, Betangs in Dayak Ngaju have transformed its building element that affected to all of its space composition and structure to $\mathbf{5 8 \%}$. It will test of time as Munoz [8] said, whether the building still exist or will pass and gone.

\section{CONCLUSION}

Betang is a big communal house that needs many people to construct. Betang in Dayak Ngaju is having the same method to construct as well as in Borneo. Wood is the most important material in betang construction and structure. Betang come in separated between the grounds and above. Betang always using pillar for its stage construction. The stair of betang designed using the ironwood log that halves of its trunk carved for the steps. Betang at first, does not use window, they were using cavities between the wall and the floor. Gable system is the style of Betang roof construction. In applying wall, using tree skin, was one of habits of Dayak Ngaju, when those walls become rotten, they were easily replaced it by cutting off the rattan tied. A house should face the East orientation to absorb the first life and lucky in they daily life. West is the sorrow of life and the death. Betang space consist of the interior space, exterior, transition, subjective space and objective space. Betangs will extinct if government and other stakeholders do not involve to protect and to conserve these structures within its planning programs. Paying attention to the existence of Betangs Dayak Ngaju have transformed its building element that affected to all of its space composition and structure to 
58\%. Picturing to the Betang Dayak Ngaju in Borneo that will loss his valuable heritage architecture. Conservation to all of betangs in Central Borneo as well as the entire island of Borneo is an inevitably. This method also suites to assess other wood traditional building.

Acknowledgements. I owe grateful for head of tourism culture agency Central Kalimantan province who had given me a tour to Betang Tumbang Anoi and Malahoi. LPPM University of Palangka Raya, which is funding this research. The last, thank to all of colleagues who have contributed so much to help this paper present in this conference.

\section{REFERENCES:}

[1] Beccari, O. "Wanderings in the Great Forests of Borneo", New York: Oxford University Press. 1904.

[2] Dianne van der Reyden, Materials Research Society Symposium Proceedings, Pittsburgh, PA, 1995, vol. 352, pp. 63- 71)

[3] Kampffmeyer, Hanno. Die Langhauser Von Zentral Kalimantan.Anacon-Verlag, Schellingstasse 23, 8000 Munchen 40. 1991

[4] Lang, Jon. "Creating Architectural Theory, the role of the behavioral sciences in Environmental Design”. VNR Company, New York. USA. 1987.

[5] Mandarin Guntur, Tari Budayanti, Yunitha, "Design of Traditional Housing" Collaboration Research UPR-Queensland University, repository LPPM University of Palangka Raya. 2018.

[6] Mandarin Guntur, Makna Ruang pada Rumah Betang Suku Dayak Ngaju di Kalimantan Tengah: Menapak Hidup ke Nirwana Tanpa Neraka. Proceeding PESAT Vol 2 | vol: | issue: | 2007

[7] Murphy, Kevin D, Change Over Time University of Pennsylvania Press Volume 4, Number 1, spring 2014, pp. 40-56

[8] Munoz V, Contemporary Theory of Conservation, Universitat Politècnica de València https://www.researchgate.net/publication/ 283234670. 2012.

[9] Frank G. Matero, Heritage, Conservation, and Archaeology, AIA Site Preservation Program. 2015.

[10] Needham, Rodney. Symbolic Classification, Goodyear publishing company, Santa Monica, California, USA. 1979.

[11] Rem, Koolhaas. "Elements of Architecture". Taschen. USA. 2018.

[12] Scharer, Hans. The conception of God among a South Borneo People. The HagueMartinus Nijhoff. 1963.

[13] Schwaner, CALM, (1852-1854) Borneo: Beschrijving van het stroomgebied van den Barito, Amsterdam: P.N. Van Kampen, 1853.

[14] Stohr, Waldemar, Das Toten Ritual der Dajak, Kommissions-verlag, E.J. Brill, 1959.

[15] Tuan, Y. "Space and Place the perspective of experience", University of Minnesota Press. Minneapolis. 1977

[16] Winzeler, "The Architecture of Life and Death in Borneo", University of Hawai'i Press, 2004.

[17] Yunitha, "Architectural Expression of Tiwah Ceremony Case Study of Dayak Ngaju Tribes Betang House in Central Kalimantan". digilib.its.ac.id. 2007. 